few weeks all the retinal structures had broken down and disappeared. The first signs of regeneration appeared after some three months; the new retina seemed to spring from the region of the ciliary processes, but there were small zones of regeneration in other regions which were due to remaining pigmented epithelium or perhaps to cells migrating from the ciliary processes. In three or four weeks the whole eye was lined by a membrane of several layers, the outermost of which was made up of rods and cones. The metabolism of the retina during the process of regeneration shows a slight increase of anaerobic glycolysis; there is no appearance of aerobic glycolysis.

HAROLD GRIMSDALE.

\title{
CORRESPONDENCE
}

\section{TREATMENT OF MUSTARD GAS LESIONS OF THE EYE}

To the Editors of THE BRITISH JOURNAL OF OPHTHALMOLOGY.

DEAR SIRS-An instruction E.M.S.I. 252 (revised) on this subject has been widely distributed to the officers, consultants and hospitals of the Emergency Medical Service. It came before the Medical Board of Moorfields Eye Hospital 'for your information.' The Medical Board considered the instruction and felt that several points in it required comment.

1. The use of albucid solution is advised at First Aid Posts and at Hospitals in cases in which the eyes have been affected by gas vapour or gas splashing. It must be pointed out that the use of sulphanilamide preparations is not directed against gas contamination but only against subsequent infection of the conjunctiva and that opinion as to its efficiency in this latter respect is far from being generally favourable.

2. No mention is made in the instruction of the very diverse lesions which may be produced by gas, most of them slight and very few of them serious.

3. No indication is given of the treatment necessary when the cornea is definitely involved and while water is advised for irrigation of the eye at an incident and at First Aid Posts, no advice is given as to the lotion to be used for the irrigations recommended at Hospitals.

It would appear that this instruction is not in fact the "result of further experience' and should be withdrawn and replaced by a 
carefully considered and detailed note based on actual experience obtained in the last war and on substantiated experimental evidence.

We are,

Yours faithfully.

F. A. JULER.

MAURICE Whiting.

Royal London Ophthalmic Hospital, June 16, 1941.

To the Editors of THE BRITISH JouRnal of OPHTHalmology.

DEAR SIRS-In your issue for March you print a notice of the Thirteenth Annual Report of the Memorial Ophthalmic Laboratory, Giza, in which your reviewer writes that "It is improbable that any ophthalmic laboratory in the World can have had the opportunity of examining 74 malignant tumours of the eye and its adnexa in a single year."

It might be of interest to record the figures for such cases at the Pathological Laboratory at Moorfields in recent years.

Last year, in which the total turnover was the lowest for many years, the figure was 77 ; for 1938 and 1939 the figures were 87 and 103 respectively.

I am, your obedient Servant,

Frank W. LAW.

Royal London Ophthalmic Hospital, June 16, 1941.

\section{NOTES}

Royal Society of The following officers have been nominated for Medicine, Section of Ophthalmology the session 1941-42. President, A. J. Ballantyne; Immediate Past President, M. L.

Hepburn; Vice-Presidents, A. E. Iles, A. F. MacCallan, J. Cole Marshall, O. Gayer Morgan, W. C. Souter, M. H. Whiting ; Hon. Secretaries, C. D. Shapland, Harold Ridley ; Members of Council : Physicians, D. H. Brinton, D. Denny-Brown, S. P. Meadows. Metropolitan Members, E. F. King, Mary A. Pugh, F. Ridley, R. S. Scott, R. E. Bickerton, V. B. Purvis, A. J. B. Goldsmith, P. M. Moffatt, H. H. Skeoch. Provincial Members : G. T. Willoughby Cashell, E. G. Recordon, G. W. Black, N. Cridland, J. G. D. Currie, G. Ian Scott ; Representative on Library Committee (Hon. Librarian of the Bowman Library), Arnold Sorsby ; Representative on Editorial Committee, E. Wolff. 